\title{
SUPRANATIONAL AGENCY AND INDIRECT GOVERNANCE AFTER THE EURO CRISIS: ESM, ECB, EMEF AND EFB
}

\author{
Tobias Tesche
}

\section{Tobias.Tesche@eui.eu}

\section{European University Institute, Department of Political and Social Sciences}

Badia Fiesolana - Via dei Roccettini 9, I-50014 San Domenico di Fiesole (FI) - Italy

ABSTRACT This article categorizes newly created and proposed Economic and Monetary Union (EMU) institutions according to a new typology that broadens the well-established agent-trustee distinction to include cooptation and orchestration as two additional modes of indirect governance. Four empirical cases from the realm of EMU governance are discussed, i.e. the European Stability Mechanism (ESM), the European Central Bank (ECB), the proposed European Minister of Economics and Finance (EMEF) and the European Fiscal Board (EFB). Empirically, it shows that supranational actors like the European Commission can bypass states through enlisting existing authority to deepen European integration.

KEY WORDS European integration, Supranationalism, Orchestration, indirect governance, Economic and Monetary Union (EMU)

\section{INTRODUCTION}

The euro area crisis has led to the creation of new institutions like the European Stability Mechanism (ESM) (Gocaj and Meunier 2013; Jones, Kelemen, and Meunier 2016; Ban and Seabrooke 2017; Seikel 2018) and the empowerment of existing ones like the European Central Bank (ECB) that took over the responsibility for micro-prudential supervision of large banks (Howarth and Quaglia 2013; Epstein and Rhodes 2016; De Rynck 2016). Remarkable about this institutional change is that it played out against the backdrop of member states' unwillingness to delegate more sovereign competences to the 
European level due to increasingly eurosceptic mass publics (Hooghe and Marks 2009; Genschel and Jachtenfuchs 2016). Supranational actors managed to expand their authority in various issue areas (Schimmelfennig 2014; Bauer and Becker 2014; Dehousse 2016). The Commission's proposal for a 'double-hatted' European Minister of Economics and Finance (EMEF) and the newly created European Fiscal Board (EFB) are indicative of a broader trend whereby supranational non-majoritarian actors 'bypass' states to deepen European integration by enlisting existing authority. While the EMEF proposal tried to co-opt the existing authority of the Eurogroup President by making him a VicePresident of the Commission and giving him control over budgetary instruments, the EFB - an advisory board of the Commission - could enlist national fiscal councils to govern fiscal policy choices of governments indirectly. In each case it is supranational agency trying to bypass potential veto players by enlisting existing authority (Abbott et al. 2015a, 6). The new intergovernmentalists predict that in the post-Maastricht era competences are primarily delegated to de novo bodies like the ESM or the ECB 'that often enjoy considerable autonomy by way of executive or legislative power and have a degree of control over their own resources' (Bickerton, Hodson, and Puetter 2015, 705). Accordingly, these bodies 'fulfil functions that could have been delegated to the Commission' and their governance structure is often controlled by member states (Bickerton, Hodson, and Puetter 2015, 705). While the ESM and the ECB tend to substantiate these claims, the EMEF and the EFB examples illustrate a counter-strategy to circumvent the constraints imposed by the new intergovernmental dynamics on supranational agency. 'Bypassing states' through enlisting existing authority could pose an alternative to the conventional strategies of deepening European integration (cf. Abbott et al. 2015a, 6).

The article's empirical focus lies on institutions operating in the realm of Economic and Monetary Union (EMU) governance, i.e. the European Stability Mechanism (ESM), the European Central Bank (ECB), the proposed European Minister of Economics and Finance (EMEF) and the European Fiscal Board (EFB). These four institutions are categorized according to the typology by Abbott et al. (forthcoming), which distinguishes between agents, trustees, co-optors and orchestrators. They differ in terms of the level of independence, mandate, legal enforcement tools and decision-making 
structure. The article assesses the downstream consequences of different modes of indirect governance for the future of EMU. The aforementioned typology enables us to delineate the scope conditions under which different modes of indirect governance emerge.

The article is structured as follows. The following section introduces the four distinct modes of indirect governance and shows how they are intertwined with supranational agency. The third section provides two empirical examples of member states granting authority to an agent (ESM) and a trustee (ECB/SSM). The fourth section illustrates how supranational actors attempt to enlist existing authority to 'bypass' states. The Commission's failed proposal for a European Minister of Economics and Finance (EMEF) and the Commission's decision to set up a European Fiscal Board (EFB) are given as examples. Finally, the article concludes with a summary of the main findings and its broader implications for European integration in the post-euro crisis era.

\section{SUPRANATIONAL AGENCY AND INDIRECT GOVERNANCE}

The following section theorizes under which conditions a certain mode of indirect governance is likely to emerge. Abbott et al. (forthcoming) have expanded principal-agent theory to include different modes of indirect governance (see Figure 1). They argue that a principal has to make two fundamental choices. First, the principal needs to decide whether to grant authority to an agent or whether to enlist existing authority. This article conjectures that the latter option presents an effective strategy for supranational actors with scarce formal authority to deepen European integration. Enlisting existing authority allows supranational non-majoritarian actors to govern without facing potential veto points. Second, principals need to choose between managing their indirect governance relationship in a hierarchical or non-hierarchical manner (Abbott et al. forthcoming). This choice is subject to a 'competence-control' trade-off (Abbott et al. forthcoming). A principal can grant an agent significant autonomy to develop her competence which might make it more difficult to control the latter. Thus, when it is particularly important to minimize agency loss, the principal should opt for delegation or cooptation as the preferred mode of indirect governance. Agency loss occurs when the agent 
opportunistically capitalizes on asymmetric information at the expense of the principal (Kassim and Menon 2003, 122) or when the delegation contract provides perverse incentives for the agent to permanently be at odds with the principal's preferences (Pollack 1997, 108). Agents that engage in capacity-building or take decisions with large distributional implications will either (1) be tightly controlled by the principal (the case of the ESM) or (2) attract co-optors that want to have more influence on the co-optee's decision-making process (the case of the EMEF proposal). However, when credible commitment problems need to be solved, the principal is more likely to prefer a nonhierarchical mode of indirect governance that emphasizes competence over control such as trusteeship or orchestration. The conventional view is that member states make credible commitments through delegation to independent trustees like the supranational ECB whose mandate is enshrined in the European Union (EU) treaties. However, it is not clear what commitment devices supranational actors have in their toolkit if they need to overcome second-order problems of credible commitment. An increasingly 'political' Commission has been struggling to act as a credible enforcer of EMU's fiscal rule framework. Given that it cannot grant authority itself, renewing the credibility of its commitment was attempted by setting up the EFB as an orchestrator that could rely on the existing authority of the national fiscal councils at the local level. Orchestrators mobilize a voluntary intermediary 'in pursuit of a joint governance goal' (Abbott et al. 2015b, 722). Orchestration can, thus, serve a dual purpose. It can be used to 'bypass' states (i.e. avoid veto points) and to reaffirm credible commitments at the supranational level.

Figure 1: Supply and demand conditions of four modes of indirect governance 


\section{SUPPLY CONDITION}

Member states granting authority

Supranational actors enlisting

authority
Minimize agency loss

\begin{tabular}{|c|c|}
\hline Delegation (ESM) & Trusteeship (ECB/SSM) \\
\hline Cooptation (EMEF) & Orchestration (EFB) \\
\hline
\end{tabular}

Source: adopted from Abbott et al. (forthcoming)

The conventional mode of delegation has been the conditional grant of authority by a principal to an agent (Pollack 1997; Thatcher and Stone Sweet 2002). The advantage of a principal-agent (P-A) relationship is that the principal maintains a degree of control because it can sanction the agent if it strays beyond its mandate (McCubbins and Schwartz 1984). Thus, this relationship is managed hierarchically ex post. Maintaining a tight grip on the agent's decision-making procedures has allowed member states to transfer considerable amounts of paid-in capital to the ESM. By pooling financial resources member states can achieve substantial economies of scale and scope that would not be attainable in the absence of delegation. Ultimately, the ESM's financial fire-power will be larger than the sum of its parts due to its superior credit rating that lowers the average borrowing costs. Linking the dispersal of financial assistance to conditionality allows creditor countries to minimize the risk of moral hazard.

In a trusteeship, 'a trustor (governor) grants authority to a trustee (intermediary)' (Abbott et al. forthcoming, 5). In contrast to a P-A relationship, it is not managed hierarchically because the trustee usually is bound by a narrow mandate and, therefore, the trustor does not rely on hard means of controlling the trustee (Majone 2001; Alter 2008). This can cause an inversion of the authority relationship ex post (Abbott et al. forthcoming, 5). During the euro area crisis, member states came to realize that they were issuing debt in a currency they had no control over anymore (De Grauwe 2012, 
2013). They had delegated the conduct of monetary policy to an independent trustee only to find that ex post the ECB could use its authority to act as a lender of last resort in order to impose conditionality on its trustors. Nevertheless, the initial grant of authority was necessary to credibly commit to price stability. Only if the trustor delegates the full authority over decision-making and enforcement in a given policy area to an independent trustee can the time-inconsistency problem be overcome (Majone 2001). This was also a crucial motivation for entrusting the Single Supervisory Mechanism (SSM) with the task of micro-prudential supervision of significant banks in the euro area (Howarth and Quaglia 2015). Dehousse $(2016,626)$ argues that 'north-south mistrust had reached such high levels that creditor countries insisted on a depoliticisation of enforcement mechanisms'. However, overcoming national supervisory forbearance and the breaking of the sovereign-bank nexus could only be credibly achieved if the new arrangement was acting completely independent of any political interference. Thus, the solution was made to entrust the ECB with this task and not the European Banking Authority (EBA).

There are several reasons why enlisting authority is an effective strategy deployed by supranational actors to deepen integration. First, granting authority is an unattractive option for supranational actors because authority is a scarce resource for them and its delegation is legally constrained (i.e. by the Meroni doctrine). Second, enlisting existing authority allows them to deepen integration without facing potential veto points controlled by member states. Third, it neither entails the mobilization of large financial resources nor does it require comprehensive monitoring. Fourth, under cooptation 'a co-optor (governor) enlists a co-optee (intermediary) with preexisting authority over particular targets; once enlisted, however, the co-optee is subject to the co-optor's hierarchical control' (Abbott et al. forthcoming, 5). In order to enlist the co-optee's authority the co-opter lures the former into the relationship by promising to boost its standing and wealth (Abbott et al. forthcoming, 5). After the cooptor 'got a foot in the door' she can increase her authority over time. The European Commission's failed attempt to make the Eurogroup President a Vice-President of the Commission ('a double-hatted EMEF') followed the cooptation pattern. By supporting the Eurogroup President (co-optee) with 
additional competences (such as a future euro area budget) the Commission (co-optor) tried to enlist its existing authority. Over time, however, the Eurogroup President's dependence on the Commission would have grown and the authority relationship could have been inversed. Thus far, the Eurogroup President is chosen intergovernmentally among the Finance Ministers of the euro area. Cooptation could have turned this into an office that gradually shifted its loyalty towards the supranational level as the dependence on the Commission would have grown.

The fourth mode of indirect governance is orchestration. Orchestrators mobilize a voluntary intermediary 'in pursuit of a joint governance goal' (Abbott et al. 2015b, 722). Like the co-optor, the orchestrator lacks hard policy instruments to govern a target directly (Abbott et al. 2015b, 720). It can govern effectively without the need for a massive transfer of competences and financial resources. It relies entirely on soft (ideational) inducements and the voluntary cooperation of intermediaries that are intrinsically motivated (Abbott et al. 2015b, 724). Thus, it is more likely to receive public endorsement. A thin legal and political basis - such as a Commission Decision - is sufficient to establish an orchestrating expert body. This allows a supranational actor to 'bypass' member states to pursue deeper integration in policy areas in which member states are loath to delegate competences because it would encroach on their own 'core state powers' (Genschel and Jachtenfuchs 2014). Fiscal policy is such a core state power that has traditionally been insulated from the reach of supranational agency. To improve the compliance with the fiscal rules the Commission set up the EFB whose task is to monitor the compliance with EMU's fiscal framework and to cooperate with national fiscal councils (Asatryan et al. 2017). However, the EFB has no enforcement capacity on its own that could coerce member states into respecting the fiscal rules. It neither possesses strong executive nor legislative powers. But it can try to enlist the existing authority of 'functionally-autonomous' national fiscal councils to govern the fiscal policy choices of governments indirectly. Thus, the Commission's EFB (orchestrator) could govern fiscal policy by relying on national fiscal councils (intermediaries) whose governance goals partially overlap with those of the orchestrator. 


\section{MEMBER STATES GRANTING AUTHORITY}

\subsection{The European Stability Mechanism (ESM) as an agent}

On the $27^{\text {th }}$ of September 2012 , the ESM became fully operational with a maximum lending capacity of $€ 500 \mathrm{bn}$ (Gocaj and Meunier 2013; Verdun 2015; Jones, Kelemen, and Meunier 2016; Ban and Seabrooke 2017; Seikel 2018). It possesses an authorized capital stock of $€ 704.8 \mathrm{bn}$ ( $€ 80.5 \mathrm{bn}$ paid-in + $€ 624.3$ callable capital). The main ESM decision-making body - the Board of Governors - consists of the Finance ministers of the euro area and is equivalent to the Eurogroup. Germany, France and Italy obtained a de facto veto in the ESM Board of Governors that allows them to individually block any decision that would lead to further risk-sharing (Henning 2017, 172). Making the Eurogroup the principal of the ESM allowed creditor countries to keep a tight control over the disbursement of financial assistance. Weighted voting rights in line with the share of subscribed ESM capital further bolstered the influence of the larger shareholders.

Several political economy considerations played a role during the ESM's creation. First, a permanent bailout mechanism would put a higher financial burden on European taxpayers due to the increased financial commitments. While the EFSF had only been backed up by guarantees of the euro area member states, a permanent bailout fund would require upfront paid-in capital (Ban and Seabrooke 2017, 12). Second, there was uncertainty about whether a limited treaty change (Art. 136 TFEU) under the fast track treaty amending procedure (Art. 48(6) TEU) was sufficient to pass the hurdle of the German Constitutional Court which later ruled that any fiscal transfers to the ESM needed parliamentary approval. Third, the new intergovernmental ESM treaty required a fresh round of parliamentary ratification, which had already proven to be politically costly in the case of its predecessor the European Financial Stability Facility (EFSF). The ability to tap the ESM was made conditional upon the prior ratification of the Fiscal Compact (Schimmelfennig 2014). Fourth, compared to the EFSF, the ESM was equipped with an expanded toolkit that entailed the ability to intervene in debt markets and to recapitalize banks directly. Both instruments were politically highly contested. At the December 2018 Euro Summit, it was decided to substitute the direct bank recapitalization 
instrument by a revolving credit line providing a common backstop for the intergovernmental Single Resolution Fund (SRF).

Why was delegation preferred over alternative modes of indirect governance? To answer this question, it is helpful to briefly review the Commission's proposal to turn the ESM into a trustee - a European Monetary Fund (EMF) ${ }^{1}$ (European Commission 2017a). The transition to a fully-fledged EMF would have entailed the transferal of new competences at the expense of a loss of control for member states if it were to be integrated into the European Union Treaty framework (Henning 2017, 251). The ESM had de facto become increasingly involved in the monitoring of conditionality and is well equipped to fulfil the same function the IMF had played in the troika (Ban and Seabrooke 2017). The division of labor between the Commission and the ESM has been regulated in detail in a dedicated MoU (European Commission and European Stability Mechanism 2018). It clearly demarcates the respective competences with regards to areas such as the preparation of financial assistance, the negotiation of conditionality and the monitoring of compliance during and after a programme. Delegating more competences to the ESM pertaining to the development and monitoring of financial assistance programmes was a key demand by the 'New Hanseatic League', a mix of fiscally hawkish eurozone and non-eurozone member states under the tutelage of the Netherlands that closely coordinated their position on EMU governance reforms (New Hanseatic League 2018). The 'Hansa' succeeded in shaping the final outcome at the December 2018 Euro Summit and in blocking some of the maximalist positions outlined in the Franco-German 'Meseberg declaration' (Federal Government of Germany 2018).

The Euro Summit on 14 December 2018 decided that the ESM will provide a common backstop to the Single Resolution Fund (SRF) in the form of a revolving credit line (European Council 2018). Furthermore, it provided clarity on the ex ante eligibility criteria for countries that want to access a precautionary conditioned credit line (PCCL) to overcome temporary liquidity shortages due to intense market pressures. Only member states that are in full compliance with the fiscal rule framework in the

\footnotetext{
${ }^{1}$ The idea had already surfaced during the onset of the eurozone crisis (Mayer 2009; Gros and Mayer 2010).
} 
two preceding years are eligible to make use of the instrument (Eurogroup 2018) ${ }^{2}$. These restrictive criteria narrow down the set of member states that could access a PCCL significantly and raises doubts whether countries in need could actually use the instrument (Claeys and Collin 2018). In case of noncompliance, a member state can still transition from the PCCL to an enhanced conditions credit line (ECCL). The outcome of the December 2018 Euro Summit leaves the existing ESM voting procedure essentially untouched. The 'New Hanseatic League' had stressed the importance of preserving the status quo of the ESM voting procedures (New Hanseatic League 2018). The Commission's EMF proposal had envisioned a streamlined decision-making procedures, i.e. 'reinforced' qualified majority voting (QMV) should apply to all decisions concerning stability support, the disbursements of funds and the deployment of the backstop. A reformed voting procedure would have turned the ESM into an independent trustee because it would have limited member states' control over the disbursements of funds. However, the ESM's main purpose was to harness the benefits of pooling financial resources and, thereby, to lower the borrowing costs for stressed member states. For these benefits to materialize, it was not necessary to enlist independent expertise. Ban and Seabrooke $(2017,10)$ observed that 'institutionally, the ESM is a 'Catch-22': it is a policy instrument intended to provide 'bailouts', in the context of the EU founding treaties that prevent bail-outs.' The only way to reconcile this institutional arrangement with the demands of mass publics in creditor countries was to demonstrate that governments are in charge of any disbursement decisions and that they will be linked to strict conditionality, i.e. compliance with the fiscal rule framework. The involvement of national parliaments was key in minimizing the risk of future agency loss for large contributing member states. Henning $(2017,173)$ pointed out that 'through domestic ratification of European decisions on financial assistance by unanimity, Germany ensured maximum control over the use of common financial facilities, fiscal exposure through them, and equally importantly, the conditions to which borrowers

\footnotetext{
${ }^{2}$ According to the ESM term sheet, 'Member States need to meet quantitative benchmarks (i.e. the debt benchmark, the minimum benchmark and a deficit below $3 \%$ of GDP) and to comply with qualitative conditions related to EU surveillance (i.e. not experiencing Excessive Imbalances and not being subject to the Excessive Deficit Procedure)' (Eurogroup 2018).
} 
were required to adhere'. Seikel (2018) showed that where new instruments encompassed risk-sharing and market-correcting elements member states maintained firm control. To further reduce the risk of moral hazard and fiscal exposure, a revamped ESM treaty will include a commitment to introduce single limb collective action clauses (CACs) which is supposed to render possible debt restructurings easier in the future. In addition, the ESM may on a voluntary and informal basis provide a forum for dialogue between its members and the private sector broadly similar to the Paris Club. In sum, delegation turned out to be the preferred mode because it provides an insurance mechanism against the agent behaving inimical to the principal's preferences. The final outcome of the ESM negotiations corroborates the finding by Degner and Leuffen (2018) that the Franco-German alliance cannot simply impose its preferred policy solution like a directoire on other member states. But it also undergirds a key claim by the new intergovernmentalists that the so-called 'de novo bodies' like the ESM often 'fulfil functions that could have been delegated to the Commission' (Bickerton, Hodson, and Puetter 2015, 705).

\subsection{The European Central Bank (ECB) as a trustee}

Majone (2001) has convincingly argued that non-majoritarian institutions such as independent central banks do not follow the conventional P-A logic. He contends that their theoretical features are best captured by the trusteeship model (see also Grant and Keohane (2005); Alter (2008); Abbott et al. (forthcoming)). According to the Anglo-American legal tradition, 'a trust is a situation where the owner of some property [...] transfers it to a "trustee" with the stipulation that the trustee should not treat it as her own but manage it for the benefit of the "beneficiary"' (Majone 2001, 113). The transferal of such far-reaching competences requires a high level of trust that the trustee will refrain from acting outside of her mandate. This is why this type of interaction is often described as a 'fiduciary relationship' (Hadfield 1997, 142).

With the creation of the ECB the euro area member states have relinquished their monetary sovereignty. By delegating authority in the realm of monetary policy to an independent central bank, 
a government can enhance its credible commitment to pursue anti-inflationary policies (Kydland and Prescott 1977). A central bank that functions as the agent of the government would lack the credibility to firmly anchor long-term inflation expectations due to the time-inconsistency problem. The euro area crisis has bolstered Majone's conceptualization of the ECB as a trustee. First, it has confirmed that the Maastricht treaty is an incomplete contract that entails open-ended commitments such as the broad objective to 'maintain price stability' (Torres 2013, 293; Leblond 2004). But it has also forcefully revealed unanticipated future contingencies that this incomplete contract failed to take into account like the threat of financial dominance, i.e. the ability of the financial industry to shift the costs of bailouts onto either the central bank or the fiscal authorities (Brunnermeier, James, and Landau 2016, 206). Second, to safeguard the viability of the currency union the ECB used its full discretion to reinterpret what constitutes monetary policy (Schmidt 2016). Draghi's London speech 'to do whatever it takes' illustrates that a less independent, hierarchically-managed central bank would not have been able to deal with the eurozone crisis in such a competent manner. On the other hand, it demonstrated that member states have few means of ex post sanctioning if they find that the trustee has acted outside of its mandate (Brunnermeier, James, and Landau 2016, 122-4). After granting authority to a trustee, the trustor's initial authority might gradually be inverted (Abbott et al. forthcoming, 5). Even though the Court of Justice of the European Union (CJEU) ruled that outright monetary transactions (OMT) and quantitative easing (QE) have not violated the treaties (Zilioli 2016; Kreuder-Sonnen 2016; Schoeller 2018), the typical ex post controls that principals usually deploy to sanction the agent if it strays beyond its mandate are less effective because a trusteeship is managed in a non-hierarchical fashion. This is the drawback of a strong commitment to price stability. Eurozone member states realized that they had become dependent on the ECB willingness to exercise its lender of last resort function. They had issued debt in a currency over which they had relinquished control (De Grauwe 2013). As the eurozone crisis proceeded, the ECB demanded structural reforms from governments in exchange for overcoming its reluctance to act as a lender of last resort (Henning 2016). This strategic interaction between the ECB and the governments took the shape of a 'game of chicken' (Henning 
2016; 2017, 49). Conditionality was a means by which the ECB tried to insulate itself from the specter of fiscal dominance but this strategy came at a reputational cost for the institution (Henning 2016, 180-5).

The unanimous decision by the European Council to activate the 'enabling clause' (Art.127(6)) that allowed it to entrust the ECB with micro-prudential supervision arose out of the need for a credible commitment to 'break the sovereign-bank nexus' (Véron 2015). The ECB was adamant that a SSM was essential for the viability of EMU. The central bank's policy entrepreneurship led to the convergence of member states' preferences and decisively contributed to its entrustment (De Rynck 2016). Two reasons explain why member states were willing to forego the control associated with delegation and instead opted for competence-based trusteeship. First, the only other existing institution that had the capacity to do the job - the EBA - had suffered from a severe loss of credibility during the failed bank stress tests of 2011 (Glöckler, Lindner, and Salines 2017, 1147). Moreover, the EBA was less independent and lacked the powerful executive and legislative decision-making powers of the ECB. Second, national banking supervisors had lost credibility due to national regulatory forbearance vis-àvis their 'national champions' (Epstein and Rhodes 2016). The SSM provided a credible commitment to end this practice by supervising significant banks directly and less significant banks indirectly from Frankfurt (Gren, Howarth, and Quaglia 2015). The downstream consequence of further empowering an already competent trustee will increase the likelihood of authority inversion. Like in the realm of monetary policy, the member states national supervisory authority might gradually be absorbed by the SSM trustee. Banking union de facto equates to a marketization of the traditionally strong bankstate ties and will, thus, reduce national economic policy discretion further (Epstein 2017, 182). As the long-term consequences of trusteeship fully emerge and banks become even less responsive to governmental preferences, member states might be increasingly inclined towards 'taking back control'. For a governor it can often be politically expedient to turn trustees into agents by bringing them under the shadow of hierarchy to minimize agency loss at the expense of endangering a credible 
commitment ${ }^{3}$. This might explain why central banks jealously guard their independence because they are acutely aware of the political dynamics that can quickly trigger an erosion of their authority if governors want to have a say in their decision-making.

\section{SUPRANATIONAL ACTORS ENLISTING AUTHORITY}

\subsection{The European Minister of Economy and Finance (EMEF) as a co-optor}

As part of its comprehensive reform package 'further steps towards the completion of Europe's EMU: a roadmap' the Commission proposed to establish a European Minister of Economy and Finance (EMEF) (European Commission 2017a). Such a 'double-hatted' EMEF would be a Vice-President of the Commission and at the same time the President of the Eurogroup. 'The European Minister would also oversee the use of EU [European Union] and euro area budgetary instruments and seek to maximise the impact in support of shared priorities' (European Commission 2017a, 10). By bundling and repackaging existing competences, the Commission could enlist the authority of the Eurogroup President. For a supranational actor with limited authority it is rational to pursue such a strategy because it allows her to govern beyond the formal scope of her authority.

The Commission's EMEF proposal demonstrates the advantages of cooptation in the context of European integration. First, a EMEF would have drawn on existing competences that would have been bundled under its new chairmanship. Second, the Eurogroup has become a key informal intergovernmental decision-making body operating at arm's length from the influence of the Commission (Puetter 2012; Hodson 2011). The 'double-hatting' would have increased the co-optee's (Eurogroup President's) standing by giving it more fiscal instruments and power but also by increasing its dependence on the co-optor (European Commission). This would have allowed the Commission to gradually invert the authority with the objective to indirectly govern the agenda of the Eurogroup meetings of the Finance ministers. However, member states had no intention of giving up their control

\footnotetext{
${ }^{3}$ Vice versa, this relationship might not hold as the case of the ESM shows. If a governor has created an agent with the objective to minimize agency loss, the governor is likely to double down on control mechanisms rather than turning it into an independent trustee.
} 
over the Eurogroup Presidency. A 'double-hatted' EMEF would have also pressured the Eurogroup to clarify its legal status and might have had positive spillover effects for its democratic legitimacy. In addition, the permanent Eurogroup President serves as the chair of the Board of Governors of the ESM. Thus, a EMEF would have given the Commission also more influence in the governance of the ESM.

Cooptation attempts to counter the new intergovernmental dynamics that give member states a firm intergovernmental grip on key decision-making fora such as the Eurogroup. It features prominently in the supranational integration toolkit because it allows actors (1) to escape the straight-jacket of their own capability deficits (Abbott et al. forthcoming), (2) to buffer the intergovernmental encroachment on their authority via the delegation of competences to de novo bodies and (3) to minimize potential agency loss. The Commission's desire to bring the Eurogroup President under its hierarchical control results from the latter's goals that have diverged from those of the Commission. Goal divergence became more pronounced during key episodes of the euro area crisis, for example, when former Eurogroup President Dijsselbloem criticized the Commission for its laxness on the interpretation of the Stability and Growth Pact (SGP) (Reuters 2016). As a consequence, co-opting the Eurogroup President became an increasingly attractive goal. Abbott et al. (forthcoming, 5) point out that 'like trusteeship, cooptation inverts authority over time, but in reverse: ex ante the co-optee is superior, as the co-optor must bid for its favor; ex post the co-optor is superior, as the co-optee must comply with its directives'. An EMEF would have gradually diverted agenda setting powers away from the member states towards the European level. However, member states have anticipated the consequences of the cooptation strategy behind the EMEF proposal and it is highly unlikely that it will ever be implemented. Many practical hurdles would have to be cleared with regards to the EMEF's legal status, political accountability and mandate (see Xanthoulis 2018). Nevertheless, the EMEF proposal neatly illustrates how cooptation as an integration strategy could allow a supranational actor to broaden its reach beyond the boundaries of its formal authority. 


\subsection{The Commission's European Fiscal Board (EFB) as an orchestrator}

The European Commission as the 'guardian of the treaties' is supposed to monitor the compliance with EMU's fiscal framework, however, it possesses only weak enforcement powers to govern effectively in the realm of 'core state power' like fiscal policy (Genschel and Jachtenfuchs 2016). To foster local ownership of the fiscal rules, the six-pack, two-pack and the Fiscal Compact mandated all euro area countries to establish 'functionally autonomous' fiscal councils at the national level (Fasone and Griglio 2013; Fromage 2017). The rationale of member states to set up fiscal councils was straightforward. The euro area crisis increased the demand for credible commitment devices that held out the promise to allay financial markets' debt sustainability concerns and to help lowering sovereign borrowing costs. An independent body of fiscal experts is supposed to produce unbiased assessments, recommendations and reports of a government's fiscal stance and macroeconomic projections. In contrast to independent central banks, fiscal councils lack the hard control over policy instruments to govern a target directly (Larch and Braendle 2018). By providing impartial fiscal assessments of the 'true' fiscal stance of a government to parliamentarians, voters, the media and other intermediaries such as credit rating agencies, a fiscal council can indirectly orchestrate fiscal discipline and, thereby, improve the compliance with the fiscal rules (Beetsma and Debrun 2017). In some euro area countries, national fiscal councils already function as reputable watchdogs with a heightened public profile that can increase the political costs for governments pursuing fiscally profligate policies (Horvath 2018).

The diffusion of fiscal councils across the European Union posed a challenge for the Commission because it threatened to lead to inconsistent rule interpretations further eroding compliance (Jankovics and Sherwood 2017, 29). The Commission's commitment to strict rule enforcement had suffered severely due to its discretionary interpretations of the various escape clauses in the SGP. To regain its lost credibility it was necessary to set up a 'watchdog for another watchdog' (Asatryan et al. 2017). Naturally, the Commission wanted to guard its role as the 'fiscal rule interpreter of last resort' (Tesche 2019). Hence, a new body was needed to cooperate with national fiscal councils, exchange 
best practice, and produce common knowledge about the fiscal rules. The idea to set up a EFB was first proposed in the Five Presidents' Report (Juncker et al. 2015, Annex 3). The EFB was formally established on 1 November 2015 and became fully operational on 19 October 2016 after the College of Commissioners appointed its members based on a proposal by the Commission President. It consists of a chair and four additional members to be appointed for 3 years (renewable once). The members of the EFB should act independently and should adopt advice by consensus. In October 2017, the EFB published its first Annual Report covering a wide range of topics from the appropriate euro area fiscal stance to SGP reform proposals (European Fiscal Board 2017). In its second Annual Report the EFB called for a major simplification of the fiscal rule framework in order to improve the compliance record (European Fiscal Board 2018). It criticized that member states had not taken advantage of the strong growth rates to achieve a marked reduction in their debt levels but also blamed the Commission for their ineffective recommendations (Valero 2018). It has been criticized that the EFB is not truly independent due to its close ties to the Commission (Bundesbank 2019, 79). In practice, this criticism has not tainted its reputation for producing independent analysis also because of its vocal criticism of the Commission's role in implementing the SGP.

The EFB could attempt to enlist existing authority by relying on national fiscal councils (the intermediaries) to orchestrate fiscal discipline indirectly. The EFB's direct interference with member states' fiscal policy choices is prohibited. Instead, it can compensate for its own capability deficits by relying on the intermediaries' local ownership and superior legitimacy with regards to the targets (Abbott et al. forthcoming). The advantage of this indirect mode of governance is that the orchestrator can effectively govern on a thin legal and political basis. The legal instrument to establish the EFB - a Commission Decision - demonstrates the Commission's reluctance to use a stronger legal basis that would have forced it to take into account the member states' preferences (Asatryan et al. 2017). This allowed the Commission to bypass member states and to write a mandate for the EFB in line with its institutional self-interest. According to the Commission's decision of 21 October 2015 (2015/1937) the EFB's task is the 'evaluation of the implementation of the Union fiscal framework, in particular 
regarding the horizontal consistency of the decisions and implementation of budgetary surveillance, cases of particularly serious non-compliance with the rules, and the appropriateness of the actual fiscal stance at the euro area and national level' (European Commission 2015). In case the EFB identifies risks to the proper functioning of EMU, it can recommend specific policy options under the SGP. Former Eurogroup President Dijsselbloem referred to the EFB as 'the big European sister of the national fiscal councils' (Foy 2015). However, national fiscal councils are adamant about safeguarding their institutional independence and are reluctant to embrace the EFB as a central coordinator of their network (Asatryan et al. 2017). As part of its December 2017 reform package, the Commission has proposed a directive that would significantly strengthen the operational capacity of national fiscal councils (European Commission 2017b). The directive would provide national fiscal councils with more enforcement tools in case of non-compliance with the fiscal rule framework. At first sight, it seems surprising that the Commission is willing to further increase the competence and independence of national intermediaries at the expense of a loss of control. However, an orchestrator can compensate for a loss of control by seeking a higher level of goal alignment between itself and the intermediaries (Abbott et al. forthcoming). This is precisely what the directive would achieve because it would make national fiscal councils complicit in punishing deviations from the medium-term fiscal objective in line with the Commission's goal to increase compliance with the fiscal rules. In sum, orchestrating fiscal discipline can be an attractive mode of indirect governance if the need for a credible commitment makes it necessary to give up on control.

Table 1: Overview of four empirical examples of indirect modes of governance

\begin{tabular}{|c|c|c|c|}
\hline & Goals & Mode & Consequences \\
\hline ESM & $\begin{array}{l}\text { - Provide financial assistance } \\
\text { at low borrowing costs } \\
\text { against strict conditionality } \\
\text { to limit financial contagion } \\
\text { - } \text { Reduce the risk of moral } \\
\text { hazard related to bailout } \\
\text { funds }\end{array}$ & Delegation & $\begin{array}{l}\text { - Member states control } \\
\text { disbursement of funds and } \\
\text { decision-making (de facto veto } \\
\text { right for large MS) } \\
\text { - Reduced fiscal exposure and } \\
\text { national audience costs }\end{array}$ \\
\hline
\end{tabular}




\begin{tabular}{|c|c|c|c|}
\hline & $\begin{array}{l}\text { - Prevent unlimited fiscal } \\
\text { transfers }\end{array}$ & & $\begin{array}{l}\text { - Preserved budgetary sovereignty } \\
\text { of national parliaments (mostly } \\
\text { in creditor countries) }\end{array}$ \\
\hline ECB/SSM & $\begin{array}{l}\text { - Severing the sovereign- } \\
\text { bank nexus } \\
\text { - Stop national regulatory } \\
\text { forbearance ('national } \\
\text { champions') } \\
\text { - Financial stability and } \\
\text { - Harness synergies between } \\
\text { micro- } \\
\text { macroprudential a } \\
\text { supervision } \\
\text { - End the era of taxpayer- } \\
\text { funded bank bailouts }\end{array}$ & Trusteeship & $\begin{array}{l}\text { - Marketization of traditionally } \\
\text { strong bank-state ties } \\
\text { - Reduction of national economic } \\
\text { policy discretion } \\
\text { - Credible commitment to } \\
\text { financial stability } \\
\text { - SSM's authority is likely to } \\
\text { increase over time } \\
\text { - Limited ex post controls to } \\
\text { sanction the trustee }\end{array}$ \\
\hline EMEF & $\begin{array}{l}\text { - Supranational control of } \\
\text { the Eurogroup Presidency } \\
\text { - Agenda-setting role for the } \\
\text { Commission in the } \\
\text { Eurogroup } \\
\text { - Align the goals of the } \\
\text { Eurogroup more closely } \\
\text { with the Commission's } \\
\text { - Gain indirect influence on } \\
\text { the ESM's decision-making } \\
\text { process }\end{array}$ & Cooptation & $\begin{array}{l}\text { - Gradually divert agenda setting } \\
\text { powers away from the member } \\
\text { states towards the European } \\
\text { level } \\
\text { - Broaden the reach beyond the } \\
\text { boundaries of the Commission's } \\
\text { formal authority } \\
\text { - Severing intergovernmental grip } \\
\text { on the ESM's and the } \\
\text { Eurogroup's decision-making } \\
\text { procedures }\end{array}$ \\
\hline EFB & $\begin{array}{l}\text { - Evaluation of the } \\
\text { implementation of the } \\
\text { Union fiscal framework } \\
\text { - Improve compliance with } \\
\text { the SGP (lower debt levels } \\
\text { and budget deficits) } \\
\text { - Propose SGP reforms } \\
\text { - Assess euro area fiscal } \\
\text { - } \text { stance } \\
\text { Cooperate with national } \\
\text { fiscal councils } \\
\text { Reestablish the credibility } \\
\text { of the Commission as a } \\
\text { trustworthy rule monitor }\end{array}$ & Orchestration & $\begin{array}{l}\text { - Limit discretionary } \\
\text { interpretations of the fiscal rules } \\
\text { - Enlist national fiscal councils to } \\
\text { govern fiscal policy indirectly } \\
\text { - Increase local ownership of and } \\
\text { compliance with the fiscal rules } \\
\text { - Commission can 'bypass' } \\
\text { member states as veto players } \\
\text { - Strengthening of horizontal } \\
\text { consistency of the decisions and } \\
\text { implementation of budgetary } \\
\text { surveillance scarce } \\
\text { - overcome credible commitment } \\
\text { problems despite scalis at the } \\
\text { authority in fiscal policy anean level } \\
\text { Europea }\end{array}$ \\
\hline
\end{tabular}




\section{CONCLUSION}

The traditional intergovernmental modes of indirect governance are delegation and trusteeship. This article has shown that by enlisting authority either through cooptation or orchestration supranational actors can deepen European integration despite new intergovernmental dynamics that tend to favor a repatriation of authority to the national level. The two cases, EMEF and EFB, indicate that the latter two modes of indirect governance feature prominently in the integration toolkit of the European Commission even if they are not always successful. Indirect governance allows supranational agency to 'bypass' potential veto points controlled by intergovernmental forces and, thereby, govern beyond the scope of their formal authority. It also provides the opportunity to reign in intergovernmental fora like the Eurogroup by coopting its President through increased powers and prestige. In the post-euro crisis period, the Commission might increasingly rely on cooptation and orchestration because they address various challenges that the European integration process faces at its current juncture. First, they offer a soft way of integration that draws on the already existing authority and capabilities of intermediaries and, hence, they do not require any additional financial resources. Thus, they lower the price of deeper integration. Second, no treaty change is required to establish a co-optor or an orchestrator because they can operate on a 'thin' legal and political basis. An ordinary Commission Decision that does not involve co-legislation by the European Parliament or the Council is often sufficient. Third, cooptation can help supranational actors to reign in powerful intergovernmental actors whose preferences have diverged. Fourth, orchestration can help supranational actors to overcome 'second-order' credible commitment problems. The creation of the EFB marked a crucial step towards regaining lost credibility in the European Union's fiscal framework. However, the article has also revealed that cooptation and orchestration can encounter several obstacles. The co-optor might not be able to offer enough benefits to the co-optee to bring him under the shadow of hierarchy. The Eurogroup President is a powerful actor in its own right and does not need to be a Vice-President of the Commission to heighten her standing because she has the backing of the collective eurozone 
Finance Ministers. Similarly, enlisting intermediaries can be challenging. National fiscal councils might prefer to pronounce their independence rather than being orchestrated by the EFB.

The cases discussed in this article indicate a tendency towards moving competences to the supranational level but not without mobilizing expertise and resources at the national level. Overall, the rapid institutional change played out against the backdrop of an unprecedented crisis that threatened the survival of the euro area as a whole (Schimmelfennig 2015). While the crisis was a major driver of institutional reform in the case of the ESM and the SSM (Gocaj and Meunier 2013; De Rynck 2016), it played less of a role in the case of the EMEF and the EFB. This is notable because the latter two examples illustrate how supranational actors could deepen integration even without strong intergovernmental backing in 'normal times'. Many scholars have interpreted the crisis through a historical institutionalist perspective in which path dependency and critical junctures ultimately have determined the crisis outcome (Gocaj and Meunier 2013; Verdun 2015; Jones, Kelemen, and Meunier 2016). A promising avenue for future research to enhance our understanding of the rapid institutional change during the euro area crisis could be to apply the concept of 'chronic instability' defined as 'multiple, frequent, and connected episodes of disjunctive change' (Bernhard 2015, 977).

\section{REFERENCES}

Abbott, Kenneth W., Philipp Genschel, Duncan Snidal, and Bernhard Zangl. 2015a. "Orchestration: Global Governance through Intermediaries." In International Organizations as Orchestrators, edited by Kenneth W. Abbott, Philipp Genschel, Duncan Snidal and Bernhard Zangl, 3-36. Cambridge: Cambridge University Press.

- - . 2015b. "Two Logics of Indirect Governance: Delegation and Orchestration." British Journal of Political Science 46 (4): 719-29. doi:10.1017/S0007123414000593.

- - - forthcoming. "Competence versus Control: The governor's dilemma." Regulation \& Governance early view: 1-18. doi:10.1111/rego.12234.

Alter, Karen J. 2008. "Agents or Trustees? International Courts in their Political Context." European Journal of International Relations 14 (1): 33-63. doi:doi:10.1177/1354066107087769.

Asatryan, Zareh, Xavier Debrun, Friedrich Heinemann, Michal Horvath, L'udovít Ódor, and Mustafa Yeter. 2017. "Making the Most of the European Fiscal Board." In ZEW Policy Brief. Mannheim: ZEW.

Ban, Cornel, and Leonard Seabrooke. 2017. "From Crisis to Stability: How to make the European Stability Mechanism transparent and accountable." edited by Leo Hoffmann-Axthelm. Berlin: Transparency International EU. 
Bauer, Michael W., and Stefan Becker. 2014. "The Unexpected Winner of the Crisis: The European Commission's Strengthened Role in Economic Governance." Journal of European Integration 36 (3): 213-29. doi:10.1080/07036337.2014.885750.

Beetsma, Roel M.W.J., and Xavier Debrun. 2017. "Fiscal Councils: Rationale and Effectiveness." In Rethinking Fiscal Policy after the Crisis, edited by L'udovít Ódor, 103-37. Cambridge: Cambridge University Press.

Bernhard, Michael. 2015. "Chronic Instability and the Limits of Path Dependence." Perspectives on Politics 13 (4): 976-91. doi:10.1017/S1537592715002261.

Bickerton, Christopher J., Dermot Hodson, and Uwe Puetter. 2015. "The New Intergovernmentalism: European Integration in the Post-Maastricht Era." JCMS: Journal of Common Market Studies 53 (4): 703-22. doi:10.1111/jcms.12212.

Brunnermeier, Markus K., Harold James, and Jean-Pierre Landau. 2016. The Euro and the Battle of Ideas. Princeton: Princeton University Press.

Bundesbank. 2019. "Monthly Report April." Frankfurt am Main: Bundesbank.

Claeys, Grégory, and Antoine Mathieu Collin. 2018. "Does the Eurogroup's reform of the ESM toolkit represent real progress?" edited by Bruegel. Brussels: Bruegel.

De Grauwe, Paul. 2012. "The Governance of a Fragile Eurozone." Australian Economic Review 45 (3): 255-68.

-- - 2013. "The Political Economy of the Euro." Annual Review of Political Science 16: 153-70

De Rynck, Stefaan. 2016. "Banking on a union: the politics of changing eurozone banking supervision." Journal of European Public Policy 23 (1): 119-35.

Degner, Hanno, and Dirk Leuffen. 2018. "Franco-German cooperation and the rescuing of the Eurozone." European Union Politics online first. doi:10.1177/1465116518811076.

Dehousse, Renaud. 2016. "Why has EU macroeconomic governance become more supranational?" Journal of European Integration 38 (5): 617-31. doi:10.1080/07036337.2016.1180826.

Epstein, Rachel A. 2017. Banking on markets: the transformation of bank-state ties in Europe and beyond. Oxford: Oxford University Press.

Epstein, Rachel A., and Martin Rhodes. 2016. "The political dynamics behind Europe's new banking union." West European Politics 39 (3): 415-37.

Eurogroup. 2018. "Term sheet on the European Stability Mechanism reform." Brussels: Eurogroup.

European Commission. 2015. "Commission Decision (EU) 2015/1937 of 21 October 2015 establishing an independent advisory European Fiscal Board." Brussels: European Commission.

- - . 2017a. "Further steps towards completing Europe's Economic and Monetary Union: a roadmap" In COM(2017) 821. Brussels: European Commission.

- - . 2017b. "Proposal for a Council Directive laying down provisions for strengthening fiscal responsibility and the medium-term budgetary orientation in the Member States." edited by European Commission. Brussels.

European Commission, and European Stability Mechanism. 2018. "Future cooperation between the European Commission and the European Stability Mechanism." Brussels.

European Council. 2018. "Euro Summit meeting." Brussels: European Council.

European Fiscal Board. 2017. "Annual Report." edited by Secretariat of the European Fiscal Board. Brussels: European Fiscal Board.

- - . 2018. "Annual Report." edited by Secretariat of the European Fiscal Board. Brussels: European Fiscal Board.

Fasone, Cristina, and Elena Griglio. 2013. "Can fiscal councils enhance the role of national parliaments in the European Union? A comparative analysis." In The Euro crisis and the state of European democracy, edited by Bruno De Witte, Adrienne Héritier and Alexander Trechsel, 264-305. Florence: European University Institute.

Federal Government of Germany. 2018. "Meseberg Declaration." In Renewing Europe's promises of security and prosperity. Berlin: The Press and Information Office of the Federal Government.

Foy, Henry. 2015. "Eurozone needs independent fiscal oversight, says Dijsselbloem." In Financial Times. London: The Financial Times Limited. 
Fromage, Diane. 2017. "Creation and Reform of Independent Fiscal Institutions in EU Member States: Incomplete and Insufficient Work in Progress?" In Constitutional Change through Euro-Crisis Law, edited by Bruno de Witte, Claire Kilpatrick and Thomas Beukers, 108-42. Cambridge: Cambridge University Press.

Genschel, Philipp, and Markus Jachtenfuchs. 2014. "Beyond Market Regulation. Analysing the European Integration of Core State Powers." In Beyond the Regulatory Polity?: The European Integration of Core State Powers, edited by Philipp Genschel and Markus Jachtenfuchs, 1-23. Oxford: Oxford University Press.

- - . 2016. "More integration, less federation: the European integration of core state powers." Journal of European Public Policy 23 (1): 42-59. doi:10.1080/13501763.2015.1055782.

Glöckler, Gabriel, Johannes Lindner, and Marion Salines. 2017. "Explaining the sudden creation of a banking supervisor for the euro area." Journal of European Public Policy 24 (8): 1135-53. doi:10.1080/13501763.2016.1184296.

Gocaj, Ledina, and Sophie Meunier. 2013. "Time Will Tell: The EFSF, the ESM, and the Euro Crisis." Journal of European Integration 35 (3): 239-53. doi:10.1080/07036337.2013.774778.

Grant, Ruth W., and Robert O. Keohane. 2005. "Accountability and abuses of power in world politics." American Political Science Review 99 (1): 29-44.

Gren, Jakub, David Howarth, and Lucia Quaglia. 2015. "Supranational Banking Supervision in Europe: The Construction of a Credible Watchdog." JCMS: Journal of Common Market Studies 53 (S1): 181-99. doi:10.1111/jcms.12271.

Gros, Daniel, and Thomas Mayer. 2010. "How to deal with sovereign default in Europe: Create the European Monetary Fund now!" CEPS Policy Brief 202.

Hadfield, Gillian. 1997. "An Incomplete Contracting Perspective on Fiduciary Duty." Canadian Business Law Journal 28 (1): 141-54.

Henning, C. Randall. 2016. "The ECB as a Strategic Actor: Central Banking in a Politically Fragmented Monetary Union." In The Political and Economic Dynamics of the Eurozone Crisis, edited by James A. Caporaso and Martin Rhodes, 167-99. Oxford: Oxford University Press.

-- . 2017. Tangled Governance: International Regime Complexity, the Troika, and the Euro Crisis. Oxford: Oxford University Press.

Hodson, Dermot. 2011. "The Rise and Fall of the Eurogroup." In Governing the Euro Area in Good Times and Bad, edited by Dermot Hodson, 38-56. Oxford: Oxford University Press.

Hooghe, Liesbet, and Gary Marks. 2009. "A Postfunctionalist Theory of European Integration: From Permissive Consensus to Constraining Dissensus." British Journal of Political Science 39 (1): 123. doi:10.1017/S0007123408000409.

Horvath, Michal. 2018. "EU Independent Fiscal Institutions: An Assessment of Potential Effectiveness." JCMS: Journal of Common Market Studies 56 (3): 504-19. doi:10.1111/jcms.12631.

Howarth, David, and Lucia Quaglia. 2013. "Banking Union as Holy Grail: Rebuilding the Single Market in Financial Services, Stabilizing Europe's Banks and 'Completing' Economic and Monetary Union." JCMS: Journal of Common Market Studies 51: 103-23. doi:10.1111/jcms.12054.

- - . 2015. "The New Intergovernmentalism in Financial Regulation and European Banking Union." In The New Intergovernmentalism: States and Supranational Actors in the Post-Maastricht Era, edited by Christopher J. Bickerton, Dermot Hodson and Uwe Puetter, 146-62. Oxford: Oxford University Press.

Jankovics, László, and Monika Sherwood. 2017. "Independent Fiscal Institutions in the EU Member States: The Early Years." European Economy Discussion Papers 067: 1-34.

Jones, E., R. D. Kelemen, and S. Meunier. 2016. "Failing Forward? The Euro Crisis and the Incomplete Nature of European Integration." Comparative Political Studies 49 (7): 1010-34. doi:10.1177/0010414015617966.

Juncker, Jean-Claude, Donald Tusk, Jeroen Dijsselbloem, Mario Draghi, and Martin Schulz. 2015. "Completing Europe's Economic and Monetary Union." In. Brussels: European Commission. 
Kassim, Hussein, and Anand Menon. 2003. "The principal-agent approach and the study of the European Union: promise unfulfilled?" Journal of European Public Policy 10 (1): 121-39. doi:10.1080/1350176032000046976.

Kreuder-Sonnen, Christian. 2016. "Beyond Integration Theory: The (Anti-)Constitutional Dimension of European Crisis Governance." JCMS: Journal of Common Market Studies 54 (6): 1350-66. doi:10.1111/jcms.12379.

Kydland, Finn E., and Edward C. Prescott. 1977. "Rules Rather than Discretion: The Inconsistency of Optimal Plans." Journal of Political Economy 85 (3): 473-91.

Larch, Martin, and Thomas Braendle. 2018. "Independent Fiscal Councils: Neglected Siblings of Independent Central Banks? An EU Perspective." JCMS: Journal of Common Market Studies 56 (2): 267-83. doi:10.1111/jcms.12577.

Leblond, Patrick. 2004. "Completing the Maastricht Contract: Institutional Handicraft and the Transition to European Monetary Union." JCMS: Journal of Common Market Studies 42 (3): 553-72. doi:doi:10.1111/j.0021-9886.2004.00518.x.

Majone, Giandomenico. 2001. "Two Logics of Delegation: Agency and Fiduciary Relations in EU Governance." European Union Politics 2 (1): 103-22.

Mayer, Thomas. 2009. "The Case for a European Monetary Fund." Intereconomics 44 (3): 138-41.

McCubbins, Mathew D., and Thomas Schwartz. 1984. "Congressional Oversight Overlooked: Police Patrols versus Fire Alarms." American Journal of Political Science 28 (1): 165-79. doi:10.2307/2110792.

New Hanseatic League. 2018. "Finance ministers from Denmark, Estonia, Finland, Ireland, Latvia, Lithuania, the Netherlands and Sweden underline their shared views and values in the discussion on the architecture of the EMU." New Hanseatic League.

Pollack, Mark A. 1997. "Delegation, agency, and agenda setting in the European Community." International Organization 51 (1): 99-134. doi:10.1162/002081897550311.

Puetter, Uwe. 2012. "Europe's deliberative intergovernmentalism: the role of the Council and European Council in EU economic governance." Journal of European Public Policy 19 (2): 16178. doi:10.1080/13501763.2011.609743.

Reuters. 2016. "Juncker's remarks on France damage credibility of Commission: Dijsselbloem." In, edited by Hugh Lawson. Reuters.

Schimmelfennig, Frank. 2014. "European Integration in the Euro Crisis: The Limits of Postfunctionalism." Journal of European Integration 36 (3): 321-37. doi:10.1080/07036337.2014.886399.

- - . 2015. "Liberal intergovernmentalism and the euro area crisis." Journal of European Public Policy 22 (2): 177-95. doi:10.1080/13501763.2014.994020.

Schmidt, Vivien A. 2016. "Reinterpreting the rules 'by stealth' in times of crisis: a discursive institutionalist analysis of the European Central Bank and the European Commission." West European Politics 39 (5): 1032-52. doi:10.1080/01402382.2016.1186389.

Schoeller, Magnus G. 2018. "Leadership by Default: The ECB and the Announcement of Outright Monetary Transactions." Credit and Capital Markets - Kredit und Kapital 51 (1): 73-91. doi:10.3790/ccm.51.1.73.

Seikel, Daniel. 2018. "Patterns of pooling and delegation after the crisis: old and new asymmetries." Journal of European Integration: 1-17. doi:10.1080/07036337.2018.1553962.

Tesche, Tobias. 2019. "'The Troika is Dead, Long Live the Domestic Troikas?': The Diffusion of National Fiscal Councils in the European Union." JCMS: Journal of Common Market Studies. doi:10.1111/jcms.12880.

Thatcher, Mark, and Alec Stone Sweet. 2002. "Theory and Practice of Delegation to Non-Majoritarian Institutions." West European Politics 25 (1): 1-22. doi:10.1080/713601583.

Torres, Francisco. 2013. "The EMU's Legitimacy and the ECB as a Strategic Political Player in the Crisis Context." Journal of European Integration 35 (3): 287-300. doi:10.1080/07036337.2013.774784. 
Valero, Jorge. 2018. "EU Fiscal Board blames Commission for ineffective recommendations." Brussels: Euroactiv.com.

Verdun, Amy. 2015. "A historical institutionalist explanation of the EU's responses to the euro area financial crisis." Journal of European Public Policy 22 (2): 219-37. doi:10.1080/13501763.2014.994023.

Véron, Nicolas. 2015. "Europe's Radical Banking Union." In Bruegel Essay and Lecture Series, edited by Stephen Gardner, 1-61. Brussels: Bruegel.

Xanthoulis, Napoleon. 2018. "The Commission's Proposal for a European Minister of Economy and Finance: Institutional Empowerment, Constitutional Tensions and the Ministerial Taboo." CERiM Online Paper Series 7/2018: 1-27.

Zilioli, Chiara. 2016. "The ECB's Powers and Institutional Role in the Financial Crisis: A Confirmation from the Court of Justice of the European Union." Maastricht Journal of European and Comparative Law (MJ) 23 (1): 171-85. 